\title{
„REŻYSERUJACC, OD RAZU WIDZĘ”. FILIP BAJON W ROZMOWIE Z IZABELĄ TOMCZYK-JARZYNA (CZĘŚĆ II)
}

Izabela Tomczyk-Jarzyna: Jako twórca świetnie odnajduje się pan zarówno w przestrzeni literatury, jaki i filmu. Napięcie pomiędzy tymi dwiema dziedzinami sztuki istnieje w zasadzie od początku w pańskiej twórczości.

Filip Bajon: Od razu powiem, że to napięcie bywało duże. Kiedyś o mało $\mathrm{z}$ tego powodu nie zwariowałem. Ale wygrzebałem się.

\section{I.T.J.: Pisząc teksty?}

F.B.: Nie. Przestając pisać. Po prostu. Przygotowywałem powieść. To, co napisałem, wydrukowałem w „Nowym Wyrazie”. Powieść nazywała się Bryk ${ }^{1}$. Wydrukowałem osiemdziesiąt stron, cała książka miała mieć około trzystu. Przerwałem pisanie i to była najlepsza decyzja. Nie dawałem rady dzień w dzień pisać, będąc bardzo młodym człowiekiem. Zawsze mówię, że jak wszedłem na plan filmowy po raz pierwszy i zobaczyłem te sześćdziesiąt osób ekipy, to odetchnąłem i doszedłem do siebie.

I.T.J.: Zaczął pan pisać jako młody człowiek. Czy mając za sobą doświadczenie obcowania za słowem przez kolejne dziesięciolecia, odczuwa pan, że zmienia się rola słowa? Czy ma pan wrażenie, jako twórca, że rola słowa z kreacyjnej coraz wyraźniej przechodzi w destrukcyjną?

F.B.: Socjologicznie obserwując rzeczywistość, dostrzec można dewaluację słowa. Myślę jednak, że ten proces zawsze zachodził. Moja babcia

1 F. Bajon, Bryk, „Nowy Wyraz” 1977, nr 6. 
prenumerowała „Przewodnik Katolicki”, jako młody człowiek czasami to czytałem. Tam też była odczuwalna degradacja słowa. Moim zdaniem proporcja między zauważeniem słowa a jego dewaluacją w tych wszystkich epokach, w których żyłem, była mniej więcej taka sama. Oczywiście masowość dezintegracji słowa internetowego jest czymś jaskrawym, przerażającym, ale to temat dla naukowców. W moim używaniu słowa, w mojej relacji „ja - słowo” generalnie nic się nie zmienia.

\section{I.T.J.: W wielu wywiadach przyznaje pan, że tą przestrzenią literacką, która pana przede wszystkim interesuje, jest powieść.}

F.B.: Tak.

\section{I.T.J.: I jednocześnie zwraca pan uwagę, że najbliższa filmowi jest poezja. Bardzo często ta poezja pojawia się w pana filmach.}

F.B.: Literatura narracyjna to nie jest film, natomiast sposób kojarzenia poetyckiego to jest film. Przyjaźniłem się głównie z poetami. Z Jerzym Górzańskim $^{2}$, z Karaskiem ${ }^{3}$, z Gąsiorowskim ${ }^{4} .$. z z całą masą poetów, którzy przychodzili do stołówki literackiej na Krakowskim Przedmieściu. Najbardziej z Jurkiem Górzańskim, który mówił przede wszystkim o słowie jako o pracy - o pracy w słowie. Nigdy się z nim nie zgadzałem, ponieważ traktowałem słowo jako użyteczne narzędzie do opisu świata.

2 Jerzy Górzański (1938-2016) - poeta, prozaik, autor słuchowisk radiowych, przez historyków literatury określany jako przedstawiciel „pokolenia 1960” lub Orientacji „Hybrydy” (zob.: Z. Jarosiński, Literatura lat 1945-1975. Mała Historia Literatury Polskiej, Warszawa 2002, s. 119-120). Pojawił się w obsadzie aktorskiej telewizyjnego filmu F. Bajona Rekord świata (1977).

3 Krzysztof Karasek (ur. 1937) - poeta, eseista, krytyk literacki. Historycy literatury określają go jako jednego z naczelnych przedstawicieli Nowej Fali, pokolenia '68 (por.: Z. Jarosiński, op. cit., s. 121).

4 Krzysztof Gąsiorowski (1935-2012) - poeta, eseista, krytyk literacki, obok Jerzego Górzańskiego, Zbigniewa Jerzyny i Jarosława Markiewicza wymieniany jako główny przedstawiciel Orientacji „Hybrydy” (zob. Z. Jarosiński, op. cit., s. 120). 


\section{I.T.J.: W pana filmach bohaterowie często posługują się słowem poetyc-} kim. Z perspektywy analitycznej fakt sięgnięcia po poezję w scenie oczywiście wpływa na jej znaczenie. Jednak mnie interesuje, jak wygląda to z pana punktu widzenia: co decyduje, że wybiera pan akurat fragment z Fausta Johanna Wolfganga von Goethego i każe go mówić Heinzowi Heinrichowi ${ }^{5}$ ? Albo, że bohater Krzysztofa Majchrzaka w Arii dla atlet ${ }^{6}$ recytuje Rękawiczkę Friedricha Schillera?

F.B.: Zawsze lubiłem tego typu zabiegi, bo, po pierwsze, świadczyły o tym, że jestem inteligentny [uśmiech], a po drugie - jednak poszerzały świat. Mam obsesję na punkcie szerokości świata. Wiem, że każda sztuka ma swoje ograniczenia i nie może pokazać go w całości. Zbyszek Rybczyński ${ }^{7}$ mówi, że obiektyw nie odwzorowuje obiektywnie świata; żeby to zrobić, obiektyw filmowy czy fotograficzny powinien mieć kształt kuli. Twierdzi również, że perspektywa to też kłamstwo. Zależy mi na maksymalnej szerokości - stąd te wstawki poetyckie, stąd mniejsza dbałość o psychologię, bo psychologia zawsze zawęża. Pewne dialogowe frazy, takie jak w Balu na dworcu w Koluszkach, są skomponowane z języka dość mocno wykreowanego - w tym sensie należy je uznać za poetyckie. Jednocześnie ważne jest, aby dbając o poszerzanie świata, nie stracić kontaktu z widzem. To wyraz mojej artystycznej strategii, ale też pewnej chytrości. OK, mogę szerzej, ale jak zrobię jeszcze szerzej, to już widz tego nie zrozumie. Zresztą wielokrotnie zdarzało się, że w pierwszym odbiorze moich filmów nie rozumiano. Po latach zobaczyłem, że dopiero teraz widzowie zaczęli je odczytywać. Jest w moim działaniu pewien rodzaj strategii. To poszerzanie świata przez asocjacje poetyckie i malarskie służy mnożeniu kontekstów, które jest jak ustawianie lustra. W każdym kontekście (lustrze) coś innego widać.

${ }^{5}$ Heinz Heinrich XV von Teuss - postać zagrana przez Jana Nowickiego, główny bohater filmu Magnat (1987) i serialu Biała wizytówka (1988).

6 Aria dla atlety, reż. F. Bajon, Polska 1979.

7 Zbigniew Rybczyński (ur. 1949) - reżyser, operator filmowy, artysta multimedialny, autor Tanga (1980), za które w roku 1983 otrzymał Oskara dla najlepszego krótkometrażowego filmu animowanego. 
I.T.J.: W jakimś sensie poszerza też pan swoje filmy, przełamując ich realizm. Bardzo często włącza pan w opowiadane historie pewne elementy spoza porządku rzeczywistości. W Magnacie takim elementem był sposób pokazania czasu, który wymusza na widzu zmianę percepcji. Jednak najlepszym przykładem będzie chyba Wahadełko ${ }^{8}$. Kiedy wydaje się, że ten realizm jest tak szalenie bliski widzowi, nagle pojawia się coś, co jest spoza porządku, czyli wielki ogórek. To sprawia, że nagle rzeczywistość pęka, zdradzając... No właśnie - co? To nie jest nadrealizm ani też realizm magiczny, bo te elementy nie powodują, że nagle cały świat przedstawiony jest im podporządkowany. Stara się pan odkryć tajemnicę rzeczywistości?

F.B.: Od razu na to nie odpowiem. Zacznę od tego, że rozwiązywanie bądź nierozwiązywanie tajemnicy, to - paradoksalnie - bardzo podobne zadania. Wynik jest inny: albo dochodzisz do jej odkrycia, albo mówisz: „nie można tego zrozumieć". Rozwiązywanie tajemnicy jest wspaniałym zadaniem scenariuszowym. Swoim studentom zawsze powtarzam, żeby w każdej sytuacji szukali tajemnicy, tak jak ja... Często odnajdywałem ją w jakiś detalach. Tak jak pani wspomniała, w ogórku na przykład.

I.T.J.: W Arii dla atlety takim przełamywaniem tajemnicy jest moment, gdy główny bohater w sylwestrowy wieczór wchodzi w przestrzeń nieznanego miasta i nagle pojawiają się przed nim postaci, których kompletnie nie potrafi zaklasyfikować. W Kamerdynerze $e^{9}$ takim momentem jest scena, w której bohaterowie idą przez zamglony las i nie wiadomo, czy są już po tamtej stronie, czy ciągle jeszcze po tej, czy to jest imaginacja Bazylego Miotke... Znowu coś nam się rozłamuje.

F.B.: Nie wiadomo. Jak zobaczył to producent - a był na zdjęciach codziennie - to po zakończeniu prac, gdy film odniósł sukces, zwierzył mi się, że chciał przerwać zdjęcia, bo nie rozumiał, co tam się wtedy działo. A był jednym ze współautorów scenariusza. To się wiąże z włączeniem takiego kryterium czy motoryki wyobraźni, które każe stanąć przed pytaniem: jak to opowiedzieć, żeby zbudować pewną tajemnicę, unikając rozwlekłego

8 Wahadełko, reż. F. Bajon, Polska 1981.

9 Kamerdyner, reż. F. Bajon, Polska 2018. 
prowadzenia akcji na zasadzie: rozstrzelali, rozstrzelali, rozstrzelali... i tak sześć miesięcy rozstrzeliwali. Chodziło więc o pewien skrót czasowy. Rzeczywistość jest pełna symboli i metafor. Tylko trudno je odnaleźć. Jeden filmowiec jest na to bardziej uwrażliwiony, inny mniej. Zdarza się, że widzisz coś i nagle dochodzi do ciebie, że to jest metafora. Tak było podczas kręcenia Wizji lokalnej j0 lub Arii dla atlety właśnie. Kluczem do wspomnianej przez panią sceny sylwestrowej jest Herman Hesse i jego Wilk stepowy. Trudno mi się ją kręciło. Nie miałem „nabitej ręki”. Znałem elementy, które powinny w niej być, natomiast nie wiedziałem, jak je sfilmować. Dopiero na planie doszliśmy do tego, żeby nie robić jednego widowiska, tylko pokazywać to pewnymi fragmentami, niespodziankami, które się zdarzają i których Góralewicz oczywiście nie rozumie. Ale się do nich zbliża... Moment, który mi tę Arię dla atlety uporządkował, znalazłem w pamiętnikach Cyganiewicza $^{11}$, które same w sobie nie były niczym nadzwyczajnym - po prostu opisywał swoje wygrane. To w Wuppertalu, to w Hamburgu... Na końcu któregoś z rozdziałów pojawiło się w nich takie zdanie: „Zdałem sobie sprawę, że bardzo lubię operę”. Było to jedno jedyne takie zdanie... Myślę sobie: „Taki gość lubi operę”. I tak dostałem klucz do tego świata - bardziej skomplikowanego, niezrozumiałego, jak w Wilku stepowym - w który mogłem go wprowadzić. Uznałem, że to może być ciekawe.

\section{I.T.J.: Napięcie pomiędzy cyrkiem a operą w Arii dla atlety jest czymś niesamowitym. Udało się panu pokazać przenikanie się tych dwóch, wydawałoby się, skrajnie różnych sztuk. Mamy w tym filmie coś, co się mocno łączy z kiczem - elementy cyrku - i coś, co chcemy łączyć ze sztuką wysoką...}

F.B.: Kiedy robiłem ten film, nie było jeszcze Trelińskiego. Opera nie przeżywała tak fantastycznego czasu. W tej chwili uwielbiam chodzić do opery. Być może jest to przewrotny rodzaj zemsty na tatusiu, który mnie targał do

10 Wizja lokalna 1901, reż. F. Bajon, Polska 1980.

11 Chodzi o pamiętnik Stanisława Zbyszka Cyganiewicza Na ringach całego świata, wydany w 1937 roku nakładem Księgarni Karoliny Piszowej. Cyganiewicz, polski zapaśnik o światowej sławie, jest pierwowzorem bohatera Arii dla atlety, Władysława Góralewicza. 
opery... Podczas oglądania spektaklu zawsze miałem poczucie tak strasznej nieprawdy... Dla mnie opera była takim samym kiczem jak zapasy. Obie te rzeczywistości wydawały mi się wtedy dość spójne.

I.T.J.: Kiedy przyjrzeć się bliżej ariom, po które pan sięga w tym filmie, można zobaczyć, jak wiele opera bierze dla siebie z cyrku, konstruując libretto, historie, postaci, żeby wspomnieć chociażby popularnych na operowej scenie klaunów. Zafascynował mnie układ pomiędzy operą i cyrkiem w Arii dla atlety oraz fakt, że pojawia się postać, która gdzieś pomiędzy tymi dwoma światami próbuje się odnaleźć. Ciekawą postacią jest również śpiewak Baptisto Messalini, który sam w sobie jest esencją kiczu, człowiekiem deprecjonującym swoją sztukę.

F.B.: Tak. Co więcej, obsadziłem w tej roli Ryszarda Pietruskiego, który grał tylko twardych facetów w typie wojskowych. Był zawsze jakimś prostym charakterem. Jednoznacznym.

I.T.J.: Mówił pan, że nie lubi filmować swoich tekstów przede wszystkim dlatego, że nie chce się pan nudzić. Pewna robota została zrobiona i jest już zamknięta.

F.B.: Tak.

I.T.J.: Sięga pan jednak chętnie po adaptacje. Istnieją teksty, które na tyle pana poruszają, że chce pan jeszcze raz sprawdzić, jak funkcjonują w obrazie. Co decyduje o tym, że sięgnął pan np. po Przedwiośnie ${ }^{12}$ czy Moralność pani Dulskiej ${ }^{13}$ ?

12 Na podstawie powieści Stefana Żeromskiego F. Bajon zrealizował w 2001 roku film o tym samym tytule oraz sześcioodcinkowy serial, nad którym praca zastała ukończona w 2002 roku i którego premiera miała miejsce w 2003 r.

13 Moralność pani Dulskiej Gabrieli Zapolskiej stała się inspiracją do zrealizowania filmu: Panie Dulskie (2015). Reżyser przygotował również filmową wersję Ślubów panieńskich Aleksandra Fredry, film pod tym samym tytułem miał swoją premierę w 2010 roku. 
F.B.: Jeżeli chodzi o etap in statu noscendi, to zwykle producent mówi np.: „przydałoby się zrobić Przedwiośnie”. Zaczynam więc myśleć i dochodzę do wniosku, że może ma rację. Wchodzę wówczas w etap poszukiwań pewnego świata i porządkowania go po swojemu. Dlatego te moje adaptacje wywoływały czasami, nie powiem, że wściekłość [śmiech], ale duże rozdrażnienie. Natomiast jeżeli chodzi o Dulską, to przyśniła mi się. A dokładnie trzy. Pomyślałem wtedy: „Rzeczywiście mogą być trzy Dulskie, tylko trzy epoki muszą być”.

\section{I.T.J.: Przyznam, że kiedy ogląda się pana film, to jego siła jest znacznie większa niż pierwowzoru, bo okazuje się, że dulszczyzna ciągnie się przez epoki. To przytłaczające, że nic nas nie jest $w$ stanie $z$ tego wyplątać, że nie da się od tego odciąć.}

F.B.: Nie, nie możemy, to jest wpisane w nasz genotyp. Dulszczyzna wiecznie wraca na poziomie obyczajowym, na poziomie kulturowym być może inne elementy są istotne. Kiedyś, mając jeszcze małą świadomość filmową, napisałem krótki, jednostronicowy scenariusz o łódce, która płynie na obrazie i zbliża się do salonu. Okazuje się, że na tej łódce są myśliwi, wylatuje stado kaczek, myśliwi zaczynają strzelać i rozstrzeliwują całą rodzinę, która siedzi przy obiedzie pod tym obrazem. Kiedy zacząłem zastanawiać się, jak to zrobić, okazało się, że muszę pokazać czas, czyli fazy zbliżania się łódki. Pomyślałem, że trzeba to przedstawić w różnych epokach kina. I to jest - jak mój pierwszy film ${ }^{14}$ - historia takiej rodziny Dulskich, którzy nie widzą, że łódka się zbliża, a gdy już dopływa, następuje, w ramach violence cinema, rozwalenie całej rodziny. Potem miejsce obrazu zajmuje telewizor; tak się kończy film. Pokazywanie tej samej historii w różnych epokach stylistycznych kina było wektorem upływającego czasu ${ }^{15}$, którym się posługiwałem.

14 Pierwszym filmem, który Filip Bajon zrealizował poza Szkołą Filmową była Videokaseta z 1976 roku.

15 Realizując Panie Dulskie, reżyser zdecydował, że poszczególne epoki (czas międzywojenny, lata pięćdziesiąte i lata dziewięćdziesiąte XX wieku) zrealizowane będą za pomocą odmiennej stylistyki zdjęć. Autorem zdjęć jest Łukasz Gutt. 
I.T.J.: Niektóre historie pan najpierw słyszy, myślę o Wahadełku ${ }^{16}$ czy chociażby o Engagement ${ }^{17}$. Pierwszy pomysł był taki, żeby skonstruować te opowieści jako słuchowisko, potem zrodził się pomysł zrealizowania na ich podstawie filmu. Z czego to wynika? Dlaczego najpierw się słyszy, a potem się widzi?

F.B.: Rzeczywiście były to dwa teksty pisane najpierw jako słuchowiska. Wynikało to z tego, że zapraszano mnie na różne konkursy pisania słuchowisk. Ponieważ miałem dużą łatwość pisania dialogów, to zapis całej opowieści odbywał się dość sprawnie. Potrzebowałem tylko pewnych pierwowzorów bohaterów - musiałem ich usłyszeć na własne uszy. To były żywe postaci, które zostały w tych słuchowiskach. W słuchowisku nie było Stalina. Bohater Wahadełka rzeczywiście się rozpoznał, odkrył, że to o nim. Natomiast Zuzia Łapicka ${ }^{18}$ doskonale wiedziała, o jakiej pomocy domowej zostało napisane w Engagement. Potem to był już tylko pewien techniczny zabieg, żeby przełożyć słuchowisko na film.

I.T.J.: Często pan powtarza, że najlepszy materiał na film to ten mający w sobie największy dramatyzm, czyli historie prawdziwe. Czy miewał pan konfrontacje z pierwowzorami swoich bohaterów, np. z tymi z filmu Magnat, z rodzinąa von Plessów? Wiadomo, Jan Henryk XVII, który jest prototypem Franzla, umiera w 1984 roku w Londynie. W tym samym roku umiera też Aleksander, czyli filmowy Konrad. Filmu nie mógł też zobaczyć autentyczny Bolko, który zmarł bardzo młodo. Niemiej potomkowie pozostali. Czy oni się do pana odzywali? Opowiada pan przecież ich historię, co więcej, dopowiada niedopowiedziane wątki.

F.B.: Nie odzywali się, co mnie dziwiło. Natomiast w jakiś sposób spowodowali, że Magnat nie poszedł w pierwszym programie telewizji niemieckiej. Śledziłem całą tę sytuację, bo w Niemczech spędzałem dość dużo czasu. Pierwszy program telewizji niemieckiej składał się z dziewięciu stacji. Żeby wyświetlić film w pierwszym programie, wszystkie stacje musiały

16 F. Bajon, Wahadetko [słuchowisko radiowe], „Dialog” 1980, nr 2.

17 F. Bajon, Engagement [słuchowisko radiowe], „Dialog” 1981, nr 3.

18 Zuzanna Łapicka (1954-2018) - dziennikarka i producentka telewizyjna. 
się zgodzić. W przypadku Magnata osiem powiedziało „tak”, a dziewiąta, w Monachium, się nie zgodziła. Szef tej monachijskiej stacji był znajomym Plessa. Pless nie ingerował, ale nie chciał go w żaden sposób urazić, dlatego się nie zgodził. Z powodu braku tej jednej zgody, film poszedł w trzecim programie. Taki był wpływ tej rodziny. Żałuję bardzo, że się z nimi nie spotkałem, ale na etapie pisania scenariusza było mi to niepotrzebne, bo miałem dosyć materiałów. Po odbiorze bym się chętnie spotkał. Przyznam, że czekałem na taki kontakt. Tym bardziej, że syn Bolka przyjeżdżał do Pszczyny już po tym, jak zrobiłem ten film. Na tak zwany wszelki wypadek zmieniłem nazwisko bohaterów na von Teuss. Duże problemy były przy Poznaniu ' $56^{19}$, ponieważ ci strajkujący żyli i patrzyli mi na ręce. Chcieli innego filmu, antykomunistycznego, patriotycznego. Ja im z góry powiedziałem, że takiego filmu nie będzie. Jak to zwykle bywa, niektórzy mieli duże pretensje duże. Postaci z filmu rzeczywiście mają swój klucz w świecie realnym. Spotkałem ich naprawdę, np. siostrę Banaszak - stąd to wywiezienie ze szpitala. Główny bohater, Zenek, w jednej scenie odgrywa takiego Józefa Robaka, scena ze śmiercią Romka Strzałkowskiego jest zrobiona jeden do jednego. Tu relacja filmu i rzeczywistości była chyba najbliższa.

\section{I.T.J.: W wywiadzie radiowym ${ }^{20}$ mówiąc o swojej autobiografii Cień po $\boldsymbol{d n i u}^{21}$, powiedział pan, że dystans odległościowy ${ }^{22}$ daje zupełnie inną optykę. Wtedy łatwiej sobie pewne rzeczy uporządkować. Czy dystans czasowy też daje taką szansę na uporządkowanie?}

F.B.: Posiadam pewien rodzaj percepcji: wchłaniam jak gąbka, ale nie wartościuję. To, co do mnie przychodzi, przyjmuję. Teraz byłem na międzynarodowych regatach na Sint Maarten i spotkałem całą masę nowych ludzi z bardzo ciekawymi zawodami. Wszystko to w sobie skumulowałem. Co to znaczy

19 Poznań '56, reż. F. Bajon, Polska 1996.

20 Zob. „Sezon na Dwójkę”, rozmowa z Filipem Bajonem, źródło: https://ninateka. pl/audio/filip-bajon-sezon-na-dwojke, [dostęp 10.03.2021].

${ }_{21}^{21}$ F. Bajon, Cień po dniu. Powieść autobiograficzna, Warszawa 2006.

22 Powtarzającym się motywem w książce jest scena, w której narrator stoi z przyjacielem na plaży Zuma Beach - ta scena często jest punktem wyjścia do opowiadania historii z przeszłości. 
w kategoriach obiektywnych i subiektywnych, czyli kategoriach mojego życia - tego jeszcze nie wiem. Ale nie spieszy mi się. Wiem, że w pewnym momencie nagle coś na nowo uruchomi we mnie porządkowanie tego, co się zdarzyło i poszukiwanie w tym sensu. Niebezpieczeństwo pojawia się wtedy, gdy sens zakładamy z góry, ponieważ grozi to tezą. Natomiast jeżeli szukamy sensu, to każdy film, książka są szukaniem sensu. Poszukiwanie tworzy dramaturgię.

I.T.J.: Mówił pan tė̇, że bycie literatem wymaga, by zmienić sposób obcowania z rzeczywistością: należy zadbać o to, by nie wchodzić w relacje, w wydarzenia, tylko stać się obserwatorem. Czy bycie reżyserem wymaga podobnego podejścia? Reżyser też jest obserwatorem?

F.B.: Wygląda to troszkę inaczej. To, co mnie fascynuje w reżyserii, to możliwość stworzenia świata. Wizualizacja opowieści jest konstrukcją niepowtarzalnego świata, którego już nikt nigdy nie powtórzy, bo jest mój. To mi się w reżyserii najbardziej podoba.

\section{I.T.J.: Taki proces nie następuje w trakcie pisania?}

F.B.: Nie, bo reżyserując, od razu widzę. Natomiast pisanie to bardziej konstruowanie emocji.

\section{I.T.J.: I dlatego męczy?}

F.B.: Tak, ale nie tylko dlatego. Pisanie wymaga czasu, wielokrotnych zmian, wymaga systematyczności. Natomiast film można zrobić w dwadzieścia dni. Tak zrobiłem Panie Dulskie. Scenariusz, który miał kilka wersji, pisałem o wiele dłużej, niż robiłem film. Myślę, że ta technika nie jest istotna. W filmie ważne jest nie opowiadanie fabuły, tylko tworzenie świata. Tego jestem pewien. 


\section{I.T.J.: Co takiego powiedział Jerzy Bossak ${ }^{23}$ na zajęciach, o których pan mówi, że to był moment, który otworzył panu oczy na reżyserię?}

F.B.: Już na pierwszych zajęciach uświadomił mi, czym jest film. Byłem przygotowany, ale nie robiłem filmu, odczytywałem filmy, odbierałem je po wielokroć. Jeżeli chodzi o lektury i stronę, nazwijmy ją, filozoficzno-socjologiczną, też byłem dość dobrze przygotowany. Bossak w jednej chwili nauczył mnie rzeczy, której ja też próbuję uczyć studentów. Nie wiem, z jakim rezultatem [śmiech]. Przyniosłem na zajęcia temat - był nim brak mieszkań w komunizmie ${ }^{24}$, a Bossak, który uczył dokumentu, powiedział mi, że prawdziwa sytuacja jest w języku dziewczynki, która mówi językiem doktora praw, a ma dziesięć lat. Podstawą myślenia filmowego jest sytuacja, a człowiek nie myśli sytuacyjnie. Mam na to pewien rodzaj uwrażliwienia. Wczoraj widziałem film Malle’a: Milou w maju ${ }^{25}$. Wcześniej go nie oglądałem. W pierwszej scenie dowiadujemy się z radia, że są zamieszki w Paryżu, 1968 rok. Słucha tego starsza pani, lecą jej łzy z oczu, a potem kamera zjeżdża niżej i pokazuje, że kroi cebulę. To jest sytuacja, ale wymyśleć ją musi reżyser.

\section{I.T.J.: Prześliczna jest ta dziewczynka. Wie pan, co się dalej z nią działo?}

F.B.: Nie wiem. A dlaczego nie wiem? Otóż chciałem zrobić jeszcze jedno ujęcie do filmu: plan pełny domu, w którym mieszkali. Mówię do Jacka ${ }^{26}$ :

23 Jerzy Bossak (1910-1989) - reżyser filmów dokumentalnych, nazywany „ojcem chrzestnym” Polskiej Kroniki Filmowej, dyrektor progrmowo-artystyczny PP „Film Polski”, profesor PWSTiF w Łodzi cieszący się ogromnym autorytetem. Stworzył instytucjonalne warunki do rozwoju polskiego dokumentu. W 1947 roku jako pierwszy polski dokumentalista za film Powódź otrzymał nagrodę na festiwalu w Cannes dla najlepszego filmu dokumentalnego. Zob. Historia polskiego filmu dokumentalnego (1945-2014), red. M. Hendrykowska, Poznań 2018.

${ }^{24}$ Chodzi o film, nakręcony w 1971 roku jako etiudę szkolną: Przyczynek do teorii językoznawstwa pod opieką artystyczną Jerzego Bossaka i Mieczysława Jahody.

${ }_{25}$ Milou w maju, reż. Louis Malle, Francja-Włochy 1990.

26 Jacek Laskus - polski operator filmowy, który od końca lat siedemdziesiątych pracuje w Stanach Zjednoczonych. Jest jedną z postaci, które pojawiają się w autobiograficznej powieści reżysera Cień po dniu. 
Chodź, weź kamerę, pojedziemy, ustawimy się i nakręcimy ten dom z daleka”. Przyjeżdżamy, a oni już tam nie mieszkają. To było jakieś dwa tygodnie później. Już się z nimi nie spotkałem. Dzięki temu, że kręciliśmy ten film, oni dostali to mieszkanie.

\section{I.T.J.: Doskonała historia!}

F.B.: Tak że kiedyś pomogłem komuś przez realizację filmu dostać mieszkanie.

I.T.J.: W jedną z pierwszych scen Magnata włącza pan fragment z Fausta. Tłumaczy go potem sam książę Hans Heinrich, kiedy mówi do syna: „Pamiętaj, Franzel, o jednym: kiedy dawałem las Hainbergowi, on dostawał węgiel, kiedy miałem zostać regentem, zostawałem rogaczem". Pomyślałam sobie, że sytuacja życiowa, o której pan opowiadał - pojechał pan robić film, a w konsekwencji ktoś dostał mieszkanie - przypomina trochę losy von Toussa: $z$ jednej strony nasza rzeczywistość jest pełna zaskoczeń, a z drugiej rodzi się pytanie, czy każdy ma swojego Mefistofelesa.

F.B.: Na pewno mam jakiegoś diabła. Chyba go nawet polubiłem. Nie zastanawiałem się nad mefistofelicznością mojego życia. Chyba tak dużo nad tym się nie zastanawiałem, zło traktowałem jako integralną półkulę dramaturgii i oczywiście wiedziałem, że jest o wiele ciekawsze od schematycznie pojętego dobra. Dramaturgia zawsze będzie po stronie zła. Muszę przemyśleć tego Mefistofelesa.

Wywiad autoryzowany, przeprowadzony 18 marca 2020 roku w Wytwórni Filmów Dokumentalnych i Fabularnych w Warszawie. 